JOURNAL

of Health Inequalities

\title{
The Great American and Polish Smokeouts, efforts to combat growing health disparities in the tobacco epidemic, and sustaining efforts to end combustible tobacco use
}

\author{
Clifford E. Douglas ${ }^{1}$, Mateusz Zatoński ${ }^{2,3}$, Kinga Janik-Koncewicz ${ }^{2,4}$, Witold A. Zatoński², \\ ${ }^{1}$ American Cancer Society, Atlanta, USA \\ ${ }^{2}$ Health Promotion Foundation, Nadarzyn, Poland \\ ${ }^{3}$ Tobacco Control Research Group, Department for Health, University of Bath, United Kingdom \\ ${ }^{4}$ European Observatory of Health Inequalities, the President Stanisław Wojciechowski State University of Applied Sciences \\ in Kalisz, Poland
}

\begin{abstract}
In the 50 years following the 1964 Surgeon General's Report, public health efforts averted an estimated 8 million deaths in the United States that otherwise would have resulted from cigarette smoking. Since 1976, the American Cancer Society has hosted the Great American Smokeout, an annual public awareness event to encourage people to quit smoking. The Smokeout has inspired similar initiatives around the world. Notably, the Great Polish Smokeout, known locally as "Quit Smoking with Us" (Rzuć palenie razem $z$ nami), underpinned the Poles' turnaround from the world's top smokers to one of the leaders in European tobacco control.

The Great American Smokeout now emphasizes the increasingly disparate nature of the problem, focusing attention on smoking in certain at-risk and frequently overlapping populations, including: individuals with less education; individuals living in poverty; members of certain racial/ethnic groups; individuals experiencing mental illness and/or substance abuse; individuals of certain sexual orientation; and members of the military. In Poland, smoking prevalence is now substantially higher among less educated inhabitants of smaller towns and rural areas. Smoking rates among young adult men and women have converged; among teenage girls they are in fact slightly higher than among teenage boys. The disparate nature of the tobacco epidemic in both countries underscores the need for approaches specifically geared toward at-risk populations in order to reduce health disparities.

The tobacco marketplace has also grown increasingly complex with the advent of e-cigarettes. In the U.S. and Poland, e-cigarette manufacturers have effectively marketed e-cigarettes to youth and young adults, causing rapid increases in vaping and spurring policy responses.

Health authorities should base policy action on the best available scientific evidence, recognizing the overwhelming impact of combustible cigarette smoking on public health, which too often fails to receive the level of attention that the leading cause of preventable death deserves.
\end{abstract}

KEY WORDS: Smokeout, tobacco smoke, nicotine delivery devices, tobacco control, Polish-American collaboration.

ADDRESS FOR CORRESPONDENCE: Prof. Clifford E. Douglas, American Cancer Society, 250 Williams St., Atlanta GA 30303, United States, e-mail: cliff.douglas@cancer.org 


\section{PAST ACHIEVEMENTS}

We like to say sometimes in the field of tobacco control that, to turn Philip Morris's old slogan for Virginia Slims cigarettes on its head, "We've come a long way, baby." And indeed we have, when one considers that, in the United States, in the 50 years following the 1964 Surgeon General's Report, health campaigners, government health authorities, and the medical profession succeeded in averting an estimated 8 million deaths that otherwise would have been caused by cigarette smoking by deterring more youth from starting and persuading more adults to quit [1].

As part of these efforts, since 1976, the American Cancer Society has hosted the Great American Smokeout, a public awareness event to encourage people to quit smoking, held on the third Thursday of November every year [2]. The Smokeout has inspired similar initiatives around the world. Notably, the Great Polish Smokeout, known locally as "Quit Smoking with Us" (Rzuć palenie razem $z$ nami), has underpinned the Poles' turnaround from the world's top smokers to one of the leaders in European tobacco control in the 1990s. The main prize of the first Polish Smokeout, organised in 1991 by the Health Promotion Foundation, was a trip to the U.S. and a meeting with Senator Edward Kennedy [3]. The Polish Smokeout also marked the beginning of close tobacco control collaboration between Polish and American researchers and tobacco control advocates [4-6]. In the later years, Poles who quit smoking could take part in a private meeting with Pope John Paul II (Photo 1). Between 1991 and the end of the pontificate of the Polish Pope, the Great Polish Smokeout was the biggest, most recognizable, and most successful public health campaign in Poland. In the years 1992-2006, around 3 million Poles claimed that they quit smoking thanks to this initiative $[6,7]$. The Great Polish Smokeout was supported financially by the state in line with the national tobacco control strategy outlined in the Anti-tobacco Law of 1995 [8]. The legislation was described by the World Health Organization as an "example to the rest of the world" [9].

The Great Polish Smokeout was one of the most powerful tools in helping to reduce the number of tobacco smokers in Poland from around 15 million in 1980 to around 8 million in 2018 (5 million men and 3 million women). Cigarette sales dropped from 100 to 40 billion cigarettes between 1990 and 2018, and smoking prevalence declined from above $60 \%$ in men and $30 \%$ in women in the early 1980 s to $23 \%$ in men and less than $20 \%$ in women in 2017 $[10,11]$. Reports published in recent years showed that Poland experienced one of the most rapid declines in smoking prevalence between 1990 and 2015 [12, 13].

\section{WHERE ARE WE TODAY?}

The $44^{\text {th }}$ annual Great American Smokeout, which took place on November 21, 2019, reminded us that, while adult smoking rates in the U.S. dropped from $42 \%$ in 1965 to $14 \%$ in 2017 , smoking still accounts for nearly one in three cancer deaths and increases the risk of cancers of the lung, mouth, larynx, pharynx, esophagus, kidney, cervix, liver, bladder, pancreas, stomach, colon/ rectum, and for myeloid leukemia. Consequently, about one out of five $(480,000)$ deaths in the U.S. is due to smoking.

The recent American event also emphasized the increasingly disparate nature of the problem in the U.S., focusing attention on the "hidden" epidemic of cigarette smoking in certain at-risk and frequently overlapping populations. As documented in a report by American Cancer Society investigators [14], these groups include:

- Individuals with less education: Fifty years ago, the difference in smoking rates between the most and least-educated was small: nearly $40 \%$ of college-educated individuals smoked compared to $45 \%$ of individuals in all other education groups. Five decades later, 6.5\% of college-educated individuals smoke, while the rate is more than three times higher among those with a high school education or less (23.1\%).

- Individuals living in poverty: Although all income groups experienced declines in smoking over the last few decades, in 2015 and 2016, current tobacco use was about $10 \%$ for adults in higher income households (greater than $400 \%$ of the Federal Poverty Level) compared to almost $25 \%$ of adults in households below the poverty line.

- Members of certain racial/ethnic groups: Individuals who are of American Indian or Alaskan Native descent exhibit the highest smoking prevalence (24.3\% men and $23.4 \%$ women), and women in this group also experienced a recent upward trend (after a nearly two-decade decline). Individuals of Asian and Hispanic/Latino descent demonstrate the lowest prevalence ( $12.6 \%$ men and $3.5 \%$ women). The reasons for these differences are not well understood, although some research suggests that social and cultural differences and/or practices may explain some of the variation.

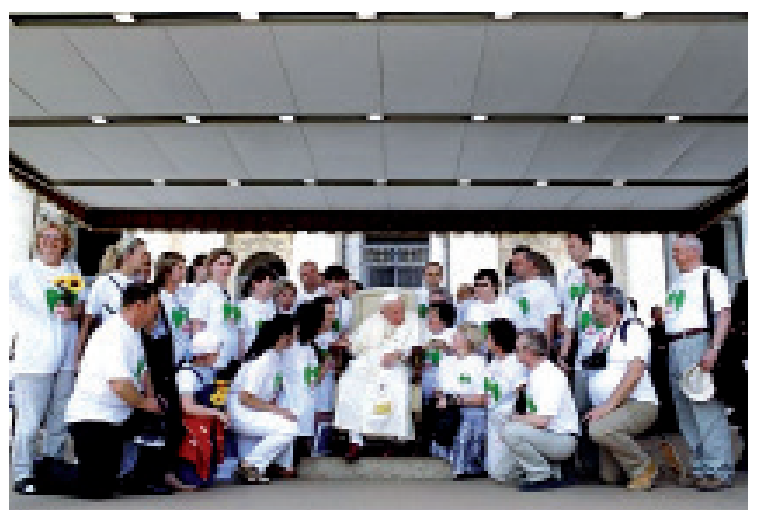

Рното 1. The last meeting of Polish Smokeout competition winners with John Paul II 
- Individuals experiencing mental illness: The burden from smoking is particularly high in individuals living with mental illness. Past 30-day cigarette smoking use among people with a past-year serious mental illness was more than double those without a past-year mental illness (27.9\% vs. $12.9 \%)$.

- Individuals experiencing substance abuse: The burden from smoking is similarly high on individuals with substance use disorders. About three-quarters of people (74\%) ages 12 and older receiving substance abuse treatment reported smoking in the past year.

- Individuals of certain sexual orientation: Smoking prevalence rates among lesbian, gay, bisexual, and transgender (LGBT) men and women in the U.S. are much higher than those among heterosexuals $(20.3 \%$ vs $13.7 \%$ ). The social stresses of living in a society that can be hostile to individuals in the LGBT community contribute to the higher prevalence.

- Members of the military: In 1980, more than half of military personnel reported smoking. By 2011, smoking rates had dropped to less than one-quarter. But for enlisted service members in the lowest four pay grades, $30 \%$ were smoking in 2011. In contrast, tobacco use in the highest six pay grades of commissioned officers had dropped below 5\%, somewhat mirroring disparities found in the civilian population.

Similar to the U.S., in Poland the pattern of factors linked to tobacco smoking has changed dramatically. In the 1970s, smoking prevalence was much higher among men than among women. Within the female population, better educated women smoked more than those less educated, and women in big cities smoked more than women from rural areas. Currently, prevalence of smoking is substantially higher among less educated inhabitants of smaller towns and rural areas. Smoking rates among young adult men and women have converged significantly; among teenage girls they are in fact slightly higher than among teenage boys.

The disparate nature of the tobacco epidemic in both countries underscores the critical need for approaches specifically geared toward these populations in order to continue to drive smoking rates down and to reduce health disparities. Increased attention to and support for novel interventions, such as targeted cessation and tobacco control efforts to counter the tobacco industry's marketing efforts, are crucial going forward to reduce tobacco's continued high impact on death and disease.

\section{NEW CHALLENGES}

At the same time, the tobacco marketplace has grown increasingly complex, with the advent of new, alternative nicotine-delivery devices (NDDs), especially electronic cigarettes ("e-cigarettes"). E-cigarettes are believed to be generally less harmful than conventional combustible tobacco products, although the long-term health effects are not known, but responses have varied considerably among countries based on differences in their legal and regulatory systems, local industry behavior, and varying traditions of harm reduction $[15,16]$. In the U.S., e-cigarettes have been placed squarely on the defensive due to the following confluence of events:

- The unfettered marketing practices of e-cigarette manufacturers, including the use of a wide array of flavors that are widely favored by youth, and the rise of Juul, which dominates the marketplace, especially among youth and young adults.

- The increase in e-cigarette use by youth. Recent reports indicate that nearly $30 \%$ of high school seniors report using an e-cigarette in the past 30 days and $12 \%$ report using an e-cigarette daily. More than 5 million children now use e-cigarettes, with flavored products being a primary driver for use.

- Inaction and delayed action by the Food and Drug Administration. As described by the New York Times [17], "The Food and Drug Administration's hands-off approach to vaping and e-cigarette regulation has backfired badly."

- The engineering practices of e-cigarette manufacturers in a weakly regulated marketplace - particularly the delivery of high levels of efficiently delivered nicotine.

- More than 2,000 cases of severe lung illnesses and nearly 50 deaths caused, according to the U.S. Centers for Disease Control and Prevention, primarily if not entirely by the use of vitamin $\mathrm{E}$ acetate oil as a thickening agent in THC vaping cartridges, which significantly amplified existing public concern with vaping products.

The lack of action from the FDA and the resulting chaos in the U.S. marketplace have led to numerous efforts at all levels of government to crack down on these products, including proposals to ban all flavors or even banning all e-cigarettes. The FDA will begin reviewing applications for premarket approval in the coming months [18], but it remains to be seen where this will all lead.

Since around 2010, Poland has also been aggressively targeted by NDD producers. The increase in prevalence of NDD use among children and teenagers, on the background of similar developments in the USA, brought these products to the attention of the state and tobacco control community [19]. It appears that the perception of e-cigarettes in Poland, among the medical and public health community, but also among large sections of the public, remains largely negative [20]. The Polish government began to address the issue, for example, by announcing an increase in the excise on e-cigarette oils from July 2020 [21].

The only representative data on prevalence of NDD use among adults in Poland comes from a study conducted by the Chief Sanitary Inspectorate in 2017 on a sample of 1,000 adults aged 15 years and above. It showed that $2 \%$ of all respondents taking part in the survey declared that they use e-cigarettes daily. Among conventional cigarette smokers, $4 \%$ of men and less than $1 \%$ of women declared they use e-cigarettes [11]. Unfortunately, the 
prevalence of experimenting with NDD use in Poland among children and youth appears high. A cross-sectional study conducted among 15-19-year-old students between 2013 and 2014 suggested that almost 30\% of participants used an e-cigarette in the past month [22]. According to the Global Youth Tobacco Survey conducted in Poland in 2016, 23\% of students aged 13-15 years ( $28 \%$ of boys, and $19 \%$ of girls) used electronic cigarettes in the past month [23]. Results from these studies present a similar picture to the situation in the U.S.

In the U.S., the primary focus is now also on protecting children, and thus the battle over e-cigarettes has largely become one over the use of flavors in these products. Many believe that a comprehensive flavor ban would have the desired effect of making e-cigarettes less appealing to youth. Some also raise the concern that a flavor ban would render e-cigarettes less appealing to adult smokers who wish to stop their combustible tobacco use and be close to an outright e-cigarette ban, decelerating progress in reducing adult smoking prevalence [24]. The New York Times editorialized in November 2019 [17] that, "The impulse to remove e-cigarettes from the market is understandable." But it also argued that "prohibition is not a good long-term solution, for a number of reasons." It then recommended that the U.S. "Learn from Britain," explaining as follows:

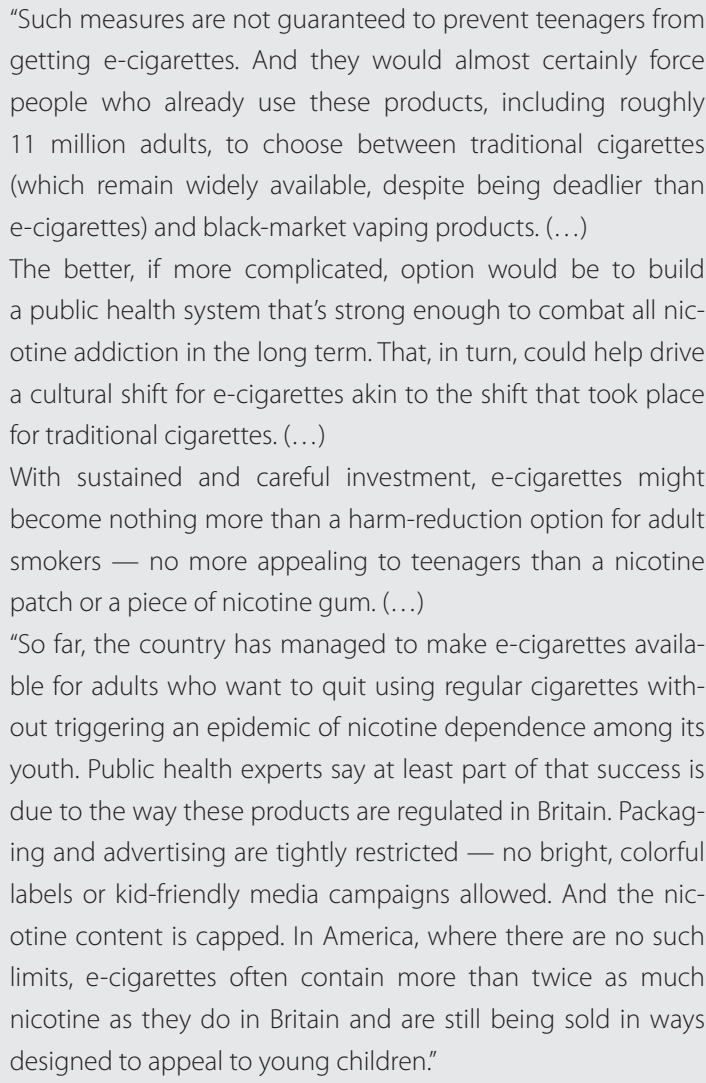

Whatever actions a country chooses to take, health authorities should base such action on the best available scientific evidence. Policies should recognize the exponentially larger impact of combustible cigarette smoking on public health, which in the current climate too often fails to receive the level of attention that the leading cause of preventable death deserves. We must retain a laser-like focus on the bull's-eye on the tobacco control target, which is ending combustible tobacco use [25].

The industry itself has hurt the cause of harm reduction. The surge in vaping among youth could ultimately sound the death knell of harm reduction in the U.S. But combined with the emergence of vaping-related pulmonary injuries and deaths, Juul's missteps in reportedly targeting underage youth and engineering its products to deliver nicotine more effectively to young users [26], which fueled the increase in youth vaping, have heightened public concern over the millions of adolescents recruited into nicotine addiction and diminished the level of sympathy and support for the concept of tobacco harm reduction. The consequence is that the vaping market could be severely weakened, if not decimated, in the U.S., which would leave us with cigarettes - quite probably the worst of all worlds for everyone but the large cigarette manufacturers.

In Poland, while NDDs present a host of new challenges and are forcefully marketed by the industry, conventional cigarettes also remain the most pressing problem. Eight million Polish smokers continue to burn through 40 billion conventional cigarettes every year, which results in 40,000 premature tobacco-related deaths annually. It is difficult to understand the Polish authorities' decision to break off with the national tobacco control strategy in 2015, a strategy which helped make Poland a global tobacco control leader in the past. Recently, an appeal by representatives of medical, scientific, and public health communities was issued to the Polish government calling on political leaders to urgently reactivate an effective tobacco control plan for the country (see Appendix 1 to the Declaration from the World Conference on Family Health, Calisia, 2019 by Aarø LE et al. on pages 129-132) [27].

\section{DISCLOSURE}

The authors report no conflict of interest.

\section{References}

1. Holford TR, Meza R, Warner KE, et al. Tobacco control and the reduction in smoking-related premature deaths in the United States, 1964-2012. JAMA 2014; 311 (2): 164-171.

2. American Cancer Society. The Great American Smokeout. Available from: www.cancer.org/smokeout (accessed: 14 October 2019).

3. Zatoński WA. The Health Promotion Foundation's appeal on the International No Smoking Day 2018. J Health Inequal 2018; (2): 87-89. 
4. Zatoński M. Poland's anti-tobacco advocacy - a historical outline. J Health Inequal 2016; 2 (1): 26-31.

5. Glynn T. Poland's journey to effective tobacco control - a brief memoir. J Health Inequal 2017; 3 (2): 143-144.

6. Zatoński MZ. State, society, and the politics of smoking in Poland, during and after communism (1960-2000). PhD thesis. London School of Hygiene \& Tropical Medicine, London 2019.

7. Fundacja Promocja Zdrowia. Lata 1991-2007 [Health Promotion Foundation in years 1991-2007]. Fundacja Promocja Zdrowia, Warszawa 2007

8. Ustawa z dnia 9 listopada 1995 r. o ochronie zdrowia przed następstwami używania tytoniu i wyrobów tytoniowych (Dz.U. z 1996 r. Nr 10 poz. 55) [Act on health protection against the consequences of consumption of tobacco and tobacco products, 1996, No. 10, pos. 53].

9. Blanke DD, Costa e Silva VD. Tools for advancing tobacco control in the $21^{\text {st }}$ century. Tobacco control legislation: an introductory guide. World Health Organization, Geneva 2004.

10. Zatoński WA, Zatoński M, Janik-Koncewicz K and the HPF team. Hundred years of cigarette smoking in Poland: three phases of the tobacco epidemic. J Health Inequal 2017; 3 (2): 118-122.

11. Kantar Public dla Głównego Inspektoratu Sanitarnego. Raport $\mathrm{z}$ ogólnopolskiego badania ankietowego na temat postaw wobec palenia tytoniu, 2017 [Kantar Public for Chief Sanitary Inspectorate. Report from the national survey on attitudes toward tobacco smoking, 2017]. Available from: https://gis.gov.pl/wp-content/uploads/2018/04/Postawy-Polak\%C3\%B3w-do-palenia-tytoniu-Raport-2017.pdf (accessed: 14 October 2019).

12. GBD 2015 Tobacco Collaborators. Smoking prevalence and attributable disease burden in 195 countries and territories, 1990-2015: a systematic analysis from the Global Burden of Disease Study 2015. Lancet 2017; 389 (10082): 1885-1906.

13. Ng M, Freeman MK, Fleming TD, et al. Smoking prevalence and cigarette consumption in 187 countries, 1980-2012. JAMA 2014; 311 (2): 183-192.

14. Drope J, Liber AC, Cahn Z, et al. Who's still smoking? Disparities in adult cigarette smoking prevalence in the United States. CA Cancer J Clin 2018; 68 (2): 106-115.

15. Zatoński M, Stokłosa M. Report from the seminar on the past, present, and future of tobacco control, Harvard University Department of the History of Science, Cambridge, Massachusetts, October 2016. J Health Inequal 2017; 3 (1): 16-23.

16. Zatoński M, Brandt A. Divide and conquer? E-cigarettes as a disruptive technology in the history of tobacco control. In: The regulation of e-cigarettes: international, European and national challenges. Gruszczynski L. (ed.). Edward Elgar Publishing, Cheltenham, UK / Northampton, USA 2019.

17. New York Times. Editorial Board. Banning e-cigarettes could do more harm than good. Only a strong public health system can conquer nicotine addiction. Available from: https://www. nytimes.com/2019/11/12/opinion/juul-vaping-bans.html (accessed: 12 October 2019).
18. US Food and Drug Administration. Premarket tobacco product applications. Available from: https://www.fda.gov/tobacco-products/market-and-distribute-tobacco-product/premarket-tobacco-product-applications (accessed: 14 October 2019).

19. Gruszczyński Ł, Zatoński M, Zatoński WA. Expert opinion for the Polish Chamber of Physicians and Dentists on innovative tobacco products and electronic cigarettes. J Health Inequal 2019; 5 (1): 67-70.

20. Ministerstwo Edukacji Narodowej. Zagrożenia związane z e-papierosami - MEN i GIS ostrzegają! [Ministry of Education. Threats due to e-cigarettes - Alert of the Ministry of Education and Chief Sanitary Inspectorate]. Available from: https:// www.gov.pl/web/edukacja/zagrozenia-zwiazane-z-e-papierosami--men-i-gis-ostrzegaja (accessed: 21 October 2019).

21. Skwirowski P. Rzeczpospolita. Akcyza tytoniowa wzrośnie [Tobacco excise will rise]. Available from: https://www.rp.pl/ Przemysl-spozywczy/311209881-Akcyza-tytoniowa-wzrosnie. html (accessed: 21 November 2019).

22. Goniewicz ML, Gawron M, Nadolska J, et al. Rise in electronic cigarette use among adolescents in Poland. J Adolesc Health 2014; 55 (5): 713-715.

23. World Health Organization. Poland Global Youth Tobacco Survey 2016. Fact sheet. Available from: https:/extranet.who.int/ ncdsmicrodata/index.php/catalog/574 (accessed: 14 October 2019)

24. Koh HK, Douglas CE. The San Francisco ban and the future of e-cigarettes. JAMA 2019; 322 (16): 1540-1541.

25. Douglas CE. A public health perspective on combating youth e-cigarette use while aiming at the bull's eye: the end of combustible tobacco use. J Health Inequal 2019; 5 (1): 31-32.

26. Creswell J, Kaplan S. How Juul Hooked a Generation on Nicotine. The New York Times. Available from: https://www. nytimes.com/2019/11/23/health/juul-vaping-crisis.html (accessed: 24 November 2019).

27. Aarø LE, Zatoński WA, Zatoński M, Wojtyła A, and advisory group. J Health Inequal 2019; 5 (2): 129-132.

\section{AUTHORS' CONTRIBUTIONS}

CED and MZ prepared a first draft of the article. All authors participated in preparing the final version of the publication. 